\title{
Analysis on Innovation and Entrepreneurship Education in Foreign Universities and its Enlightenment to Domestic Universities
}

\author{
Zhanfeng Gao ${ }^{\mathrm{a},}{ }^{*}$, Wenjiang $\mathrm{Wu}^{\mathrm{b}}$, and Jianchao Zhang ${ }^{\mathrm{c}}$ \\ Engineering Training Center, Shijiazhuang Tiedao University, 17\# East Road, Second North Ring, \\ Shijiazhuang, China

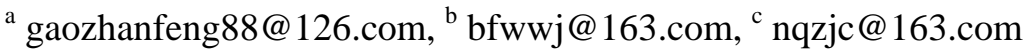 \\ *corresponding author
}

Keywords: innovation and entrepreneurship, education, foreign universities, domestic universities

\begin{abstract}
With the rapid development of the international integration process, the global phenomenon of increased competition has emerged, and innovation and entrepreneurship have become the main driving force for economic development in the 21st century. Since the Ministry of Education issued the "Opinions of the Ministry of Education on Promoting Innovation and Entrepreneurship Education in Colleges and Universities and Self-employment of College Students" in 2010, domestic innovation and entrepreneurship education has developed rapidly in various universities, but there are still many problems. This paper takes college students from developed countries as the research object, and focuses on the basic situation of innovation and entrepreneurship education in America, Britain and other European countries' and Japanese universities. In addition, their outstanding characteristics of success in innovation and entrepreneurship education were summarized. Some inspirations for the development of innovation and entrepreneurship education in Chinese universities are put forward to provide a useful reference for China’s colleges and universities.
\end{abstract}

\section{Introduction}

What today's society needs is no longer just students holding books. The more urgent need is for students with innovative and entrepreneurial abilities. Only students with good comprehensive quality and innovative entrepreneurial ability can integrate into society better, create more and greater social value, and achieve self-worth better. The 17th National Congress of the Communist Party of China put forward the development strategy of "improving independent innovation capability, building an innovative country" and "promoting employment through entrepreneurship". In May 2015, the "Implementation Opinions on Deepening the Reform of Innovation and Entrepreneurship Education in Colleges and Universities” issued by the State Council marked the rise of innovation and entrepreneurship education as a steady advancement of the national strategy. Li Keqiang repeatedly emphasized "innovation and entrepreneurship" in the "Government Work Report" in 2015 and proposed the "Internet+" action plan for the first time [1]. This shows that cultivating college students' innovative entrepreneurship and improving their ability to innovate entrepreneurial abilities is the top priority of China's higher education and the main theme of the development of the current era.

College students are one of the most innovative and entrepreneurial potential groups. Carrying out innovation and entrepreneurship education in colleges and universities and encouraging students to start their own businesses are important strategic measures for the education system to study and practice the scientific concept of development and serve the construction of an innovative country. It is an important way to deepen the teaching reform of higher education, cultivate students' innovative spirit and practical ability, and it is also an important measure to promote employment through entrepreneurship and promote full employment of college graduates. Therefore, how to cultivate students' ability of innovation and entrepreneurship has become the most important issue for colleges, society, government and educators. Foreign countries have carried out some research 
on innovation and entrepreneurship education early and have achieved some successful methods and experience. The research status and characteristics of foreign innovation and entrepreneurship teaching was analyzed. We hope to provide reference for domestic innovation and entrepreneurship education and promote the professional development of teachers and the level of domestic innovation and entrepreneurship education.

\section{Development of Innovation and Entrepreneurship Education in Universities Abroad}

The research and practice of innovation and entrepreneurship education in foreign countries started early and developed rapidly. The system construction of innovation and entrepreneurship education in colleges and universities has become mature, and the experience is extremely rich, which is worth learning and using for reference. Since 1947, more than 1,800 colleges and universities in America have offered courses on innovation and entrepreneurship education, and their theories on innovation and entrepreneurship education have formed a fairly complete system. At least $45 \%$ of British universities offer entrepreneurship education courses. Australia attaches great importance to innovation and entrepreneurship education teacher training, many teachers are entrepreneurs with solid theoretical basis and rich practical experience. In addition, Japan and Singapore have gradually integrated innovation and entrepreneurship education into the national education system, providing a number of funds for students to carry out innovative and entrepreneurial practice activities. Canada, New Zealand and other countries are also in full swing development of innovation and entrepreneurship education [1-8]. The basic situation of innovation and entrepreneurship education in American, British and Japanese universities was analyzed in this paper.

\subsection{Overview of innovation and entrepreneurship education in American universities}

American is the first country to carry out innovation and entrepreneurship education for college students. After 70 years of development, innovation and entrepreneurship education America is ahead of other countries in theory and practice. Since 1947, Harvard University opened the first course in the history of innovation and entrepreneurship education in U.S. universities; Batson Business School claims to be "focused on entrepreneurship education" and set up the course of innovation and entrepreneurship in 1967, and then various universities have set up relevant innovation and entrepreneurship research centers. After 2000, American universities have set up their own innovation and entrepreneurship research centers. New entrepreneurship education has shown a systematic and large-scale trend, after a long period of exploration and practice, the emergence of the United States Baisen Business School, Binzhou University, Stanford University, Crayton University and other well-known entrepreneurial research centers. Among them, the renowned entrepreneurship curriculum system reform of Bessen Business School and the innovation and entrepreneurship education model of Stanford University have great influence. The greatest achievement of innovation and entrepreneurship education should be the birth of the worldrenowned "Silicon Valley". So far, the entrepreneurship rate of American college students is as high as $25 \%$, far higher than that of other countries in the world. The state also issued a number of laws and regulations to protect the college students' entrepreneurship legally. For example, Congress passed the Small Business Act in 1953, the Reagan Administration passed the Economic Recovery Tax Act in 1981, and the Tax Reform Act in 1986.

American colleges and universities have taken the concept of innovation and entrepreneurship as an indispensable ideological concept for infrastructure construction, set up innovation and entrepreneurship education as a professional research direction, and formulated a complete set of characteristic innovation and entrepreneurship education class system and teaching plan. It has the following characteristics: (1) a relatively perfect discipline system; (2) a clear goal of cultivating entrepreneurship personnel; (3) a relatively outstanding faculty; (4) rich and practical practical practical practical teaching activities; (5) a more systematic quality curriculum. 


\subsection{Overview of innovation and entrepreneurship education in British universities}

The policies and regulations on innovation and entrepreneurship in Britain are formulated and perfected by the Ministry of Education and Skills, the Ministry of Finance, the Ministry of Trade and Industry and the Office of the Prime Minister. The funds for innovation and entrepreneurship in colleges and universities mainly rely on the unified funding of the government. The coordination between policy-making and funding provides a strong guarantee for the innovation and Entrepreneurship of college students. Innovation and entrepreneurship education in British universities began in 1982. In order to solve the employment problem of college students, the British government has introduced the project of "college students' entrepreneurship" to encourage college students' independent innovation and entrepreneurship. The British government stopped the project because it was mainly for the utilitarian purpose of solving the employment problem and lacked motivation. Afterwards, the British government, aware of the necessity of entrepreneurship education, supported, guided and regulated the policy, and guaranteed the development of innovation and entrepreneurship education in colleges and universities in terms of manpower, material resources and policies. Since then, entrepreneurship education in Britain has been incorporated into formal education. In 2004, the British government launched the entrepreneurship competition, which has a great role in promoting the entrepreneurial enthusiasm and quality of college students. In the same year, the British College Student Entrepreneurship Council was established to take charge of entrepreneurship education throughout the country, further promoting the systematic development of innovation and entrepreneurship education in Britain. It is worth mentioning that the more advanced business incubator in Britain is the entrepreneurship Park incubator, in which the Cambridge Sino-British Business Park, Oxford University Science Park, Birmingham Science Park and so on are well-known, which provides a strong support and help for the development of entrepreneurship education in Britain, the innovation and progress of university students and the development of business projects.

\subsection{Overview of innovation and entrepreneurship education in other European countries}

Including the British, the European Union now has 9 countries or regions such as Finland, Denmark, Sweden to develop a special strategy for entrepreneurship education. In 2006, the European Commission issued a further report on entrepreneurship education, linking entrepreneurship education with the development of a unique entrepreneurial culture in Europe. Germany's comprehensive innovation capability ranks third in the world and the first in Europe. In Germany, half of the universities are based on applied innovation, and the proportion is gradually increasing. Germany started the research on entrepreneurship and innovation with universities as the starting carrier. The establishment of German innovation and entrepreneurship ecosystem benefits from the support and effective guidance of multi-level government departments, central and local Policy-based Bank financing. And its own innovation and entrepreneurship type of social organizations developed, comprehensive system and solid foundation, to ensure the smooth and effective operation of the ecosystem pipeline. The University of Twente in the Netherlands is a research university full of entrepreneurship. Its education and training are at the top of the European Union. Its influence in science and technology ranks sixth in Europe. The success of a school owes much to its distinctive entrepreneurial characteristics $[4,7,8]$.

Through various policy orientations, EU and member governments encourage universities to integrate entrepreneurship education into the development of different disciplines and provide entrepreneurship courses and activities for all students interested in entrepreneurship. In Britain, for example, the 2007 Higher Education Entrepreneurship Survey in England showed that 11\% of college students participated in Entrepreneurship education, 36\% of which were in the course of entrepreneurship, and the remaining 64\% were out of the course. Within the curriculum, business schools and management schools are the main providers of entrepreneurship education, accounting for $61 \%$; the remaining $9 \%$ are provided by engineering schools, $8 \%$ by arts and design disciplines, and $4 \%$ by science [9]. 


\subsection{Overview of innovation and entrepreneurship education in Japanese universities}

The Japanese government supports innovation and entrepreneurship in policies and funds. The Japanese government has promulgated a series of relevant laws and regulations, which provide strong support for university innovation and entrepreneurship in national policies. Innovation and entrepreneurship education in Japan also began in the 1980s, initially in the form of innovation and entrepreneurship in colleges and universities, then to the 90's internship system, the effect is not significant. In 1995, the implementation of the Basic Law of Science and Technology and the policy of establishing a nation through science and technology greatly promoted the development of innovation and entrepreneurship education in Japan. After 2000, along with the formal proposal of “entrepreneurship spirit”, innovation and entrepreneurship education in Japanese universities has entered a rapid development stage. Among them, the collaborative mode of industry, government and school is the prominent feature of innovation and entrepreneurship education in Japan, that is, in the development process of innovation and entrepreneurship education, the advantages of resources in the whole society are concentrated, and the government and the trustee are formed. Or independent entrepreneurship education organizations and universities tripartite co-development model, the government provides policy and financial support for innovation and entrepreneurship education, enterprises provide economic and technical support for innovation and entrepreneurship education, universities and primary and secondary schools play their main role in innovation and entrepreneurship. Innovation and entrepreneurship education in Japanese universities has the following characteristics: (1) government-led, universities and society to assist the government to complete innovation and entrepreneurship education; (2) innovation and entrepreneurship education is very regional; (3) innovation and entrepreneurship education system has consistency; (4) venture enterprise plan for innovation and entrepreneurship education development outstanding results.

\section{Common Characteristics of the Foreign Successful Experience}

Through the above analysis of foreign innovation and entrepreneurship education, it is not difficult to find that the characteristics of innovation and entrepreneurship education in developed countries have many common characteristics and experience worth learning.

\subsection{Government support and effective guidance}

The United States Congress passed the Small Business Act in 1953, the Reagan Administration passed the Economic Recovery Tax Act in 1981, the Tax Reform Act in 1986, and the Congress passed three bills to extend the highly competitive Small Business Innovation Research Program among 1992-2012. It has successively supported many famous international enterprises such as Microsoft Corp and Intel.

The EU and its member governments have adopted various policy orientations, including the United Kingdom. At present, the EU has formulated special strategies for entrepreneurship education in 9 countries or regions, such as Finland, Denmark and Sweden. The UK's policies and regulations on innovation and entrepreneurship are formulated and perfected by the Ministry of Education and Skills, the Ministry of Finance, the Ministry of Trade and Industry and the Office of the Prime Minister. The UK Science and Entrepreneurship Center and the National College Students Entrepreneurship Council have been established as the special administrative agencies to ensure the effective implementation of the policies and regulations.

The Japanese government has promulgated a series of relevant laws and regulations to give strong support to university innovation and entrepreneurship in national policies. Diversified financing channels including government and social sectors have been established to provide financial support for innovation and entrepreneurship education in Japanese.

\subsection{Relatively complete curriculum system for innovation and entrepreneurship}

A series of innovation and entrepreneurship courses have been developed and a comprehensive curriculum system for innovation and entrepreneurship education has been established. American 
colleges and universities take innovation and entrepreneurship education as a professional research direction, and have formulated a complete set of characteristic innovation and entrepreneurship education class system and teaching plan. The innovation and entrepreneurship education in Britain has changed from the standard education of entrepreneurship course to the systematic education of specialty and degree, and has its own distinct culture and characteristics. Japan's innovation and entrepreneurship education system has continuity from primary and secondary schools to universities. The European Union encourages universities to integrate entrepreneurship education into the development of different disciplines, providing entrepreneurship courses and activities for all students interested in entrepreneurship.

\subsection{Pay attention to the construction of teaching staff}

American innovation and entrepreneurship education develops well mainly because it has a team of full-time and part-time teachers with deep theoretical foundation and strong practical experience. Full-time teachers have both extensive theoretical foundation and rich practical experience, mostly playing the dual roles of professor and businessman; part-time teachers are mainly composed of entrepreneurs, venture capitalists and accomplished alumni. The United States attaches importance to the practical training of innovative entrepreneurship teachers. The International Association for Entrepreneurship Education organizes teachers to participate in simulated entrepreneurship activities. Japan has strengthened the training of teachers' theory and practical knowledge through cooperation in production and learning. For example, by employing people from the community to teach in colleges and universities, university teachers to exercise in enterprises, teachers to visit enterprises and other programs, etc.

\subsection{Adopting diversified practice teaching, emphasizing integration of production, teaching and research}

Through the imitation of various innovation and entrepreneurship competitions, students can get the perceptual experience of innovation and entrepreneurship, and form a good atmosphere of innovation and entrepreneurship. Making full use of the resources of the government, enterprises and society, giving full play to the role of the university's own educational resources, forming an innovative and entrepreneurial education system with the integration of production, teaching and research.

The U.S. government not only provides financial assistance for entrepreneurial enterprises, but also broadens the sources of funding for entrepreneurial enterprises through policy guidance; a large number of specialized entrepreneurial counseling institutions have been created to provide targeted guidance and advice in management, service, technology, marketing, personnel and other aspects.Colleges and universities cooperate deeply with enterprises to provide students with practical opportunities, so that students can accumulate relevant enterprise experience. The university has formulated a number of supportive systems and measures, such as the use of flexible school system to encourage college students to start their own businesses.

Innovation and entrepreneurship education in Britain, with the participation of the whole society led by the government, strong teachers and perfect curriculum, has formed a mutually reinforcing and multi-interactive system. The funds for innovation and entrepreneurship in colleges and universities mainly depend on the unified appropriation of the government. The coordination between policy making and appropriation of funds provides a strong guarantee for the innovation and Entrepreneurship of college students.

Japanese universities pay attention to the integration of their own educational resources to form a unique "production, government, learning" integrated innovation and entrepreneurship system, and make full use of the synergy of enterprises, governments and universities themselves.

\section{Enlightenment from Foreign Successful Experience to Domestic Universities}

The gap between China's higher education and foreign higher education lies mainly in the cultivation of innovative and entrepreneurial talents. The foreign models also bring some 
enlightenment to our innovative education.

\subsection{Enhance college students' sense of identity for innovation and entrepreneurship}

In order to cultivate diversified talents, colleges and universities in our country should first establish the concept of innovation and try their best to mold the cultural atmosphere of innovation and entrepreneurship, actively create a good cultural atmosphere of innovation and entrepreneurship, and stimulate the innovative and entrepreneurial will and passion of college students.

\subsection{Build a sound social security system supported by the government}

Governments at all levels should not only give college students support in policies and laws and regulations, and strive to promote the implementation of policies, but also encourage the establishment of various types of innovation and entrepreneurship funds to help students solve the financial problems of new ventures to a certain extent with the help of various social forces. Otherwise, the entrepreneurship of university students in China will always be a mere formality, and can not achieve tangible results.

\subsection{Build a reasonable innovation and entrepreneurship education system}

We should clarify the position of innovation and entrepreneurship education in the process of education and teaching, set up the course of innovation and entrepreneurship reasonably, and perfect the teaching links, especially strengthen the practical teaching of innovation and entrepreneurship. In the course of curriculum design, we should take into account the characteristics of students of different majors and different stages of learning, and integrate innovation and entrepreneurship education with talent training program, so as to cover all majors, layers and key points [11].

\subsection{Attach importance to the construction of teaching staff}

Optimize the structure of teaching staff, improve theory and enhance the level of practical teaching. At present, the overall quality of entrepreneurship teachers in China's colleges and universities is not high, college-based teachers lack practical knowledge of entrepreneurship, and some managers lack theoretical knowledge of entrepreneurship[11]. Therefore, it is an important task for the development of innovation and entrepreneurship education to train the "doublequalified" teachers. Colleges and universities should strengthen the training of teachers to improve their practical ability of innovation and entrepreneurship; at the same time, they should also actively recruit talents with both practical experience and theoretical knowledge from enterprises and institutions to teach in colleges and universities.

\subsection{Strengthening the cooperation mode of industry, university and research institute}

Schools should actively carry out innovative practice education with scientific research institutes, enterprises, companies and other social organizations by co-constructing innovative and entrepreneurial laboratories and practice bases, promote the development of the mode of "production, learning and research", attach importance to the mutual transformation between practical application and scientific research, and cultivate students' innovative spirit and entrepreneurial consciousness. It will further promote the sound development of innovation and entrepreneurship education in colleges and universities.

\section{Conclusion}

In short, the rapid development of China's economy has put forward higher requirements for the talents trained by colleges and universities, so colleges and universities should attach great importance to the cultivation of college students' innovative and entrepreneurial spirit and ability to enhance. In order to avoid fewer detours, we should conscientiously sum up and draw lessons from the successful experience of innovation and entrepreneurship education in foreign universities. We should break away from traditional educational concepts and actively explore educational concepts, 
discipline system construction, faculty building and student practice. Coordinating the strength of the government, society, enterprises and schools, and constructing the innovative education mode in line with the national conditions in the "Internet +" era to cultivate college students' innovative consciousness and innovative ability, and train innovative talents to meet the needs of economic and social development.

\section{Acknowledgements}

This research were financially supported by the Hebei province higher education teaching reform research and practice project "Exploration and Practice on the Cultivation of College Students' Hierarchical and Gradual Innovative Ability(2017GJJG124)” and the Hebei province research and practice project on innovation and entrepreneurship education reform " Construction of innovative training platform for engineering training center for the whole school(2017CXCY080)", and educational scientific research projects of the Ministry of education higher education engineering training teaching steering committee "Exploration and Practice of College Students' Innovative Education Based on Engineering Training Platform (JJ-GX-JY201747)”.

\section{References}

[1] Yan Zhao. (2017) Experience of innovation and entrepreneurship education in foreign universities. CO-Operative economy \& Science, 9, 78-78.

[2] Jiasu Lei. (2017) Analysis on the development of innovation and entrepreneurship education at home and abroad. Science and China Youth Technology, 2, 26-29.

[3] Chongxu Qi. (2016) On the development of innovation and entrepreneurship education for college students at home and abroad. Modern Economic Information, 9, 394.

[4] Qionghui Duan, Feng Qin, Juyin Li and Yong Li. (2016) Teaching status of innovation and entrepreneurship education abroad. J. Examination weekly, 2, 19-20.

[5] Jie Hao, Aihua Wu and Yongfeng Hou. (2016) the construction and Enlightenment of American innovation and entrepreneurship education system. Research in Higher Education of Engineering, 2,7-12.

[6] Tao $\mathrm{Hu}$ and Li Shen. (2013) Enlightenment of overseas innovation and entrepreneurship education mode to Chinese Universities. China University Teaching, 2, 91-94+90.

[7] Xiaozhou Xu and Weihui Mei. (2010) The strategic choice of entrepreneurship education in Universities: the American model and the EU model. Journal of Higher Education, 6,98-103.

[8] Zhiqiang Wang. (2014) Integration and Pluralism: the development trend and Enlightenment of EU entrepreneurship education. Educational Research, 4,145-151.

[9] National Council for Graduate Entrepreneurship. Re2 port on Enterprise and Entrepreneurship in Higher Ed2 ucation [ R/ OL ]. http :/ / www. ncge. com/ uploads/ NCGE_Report_2007. pdf.

[10] Jun Wang. (2016) Comparison and reference of innovation and entrepreneurship education in Colleges and universities at home and abroad. Chuangxin Yu Chuangye Jiaoyu, 4, 99-103.

[11] Zhanfeng Gao, Wenjiang W, Zhounan Li and Jianchao Zhang. (2017) Research on innovative education mode of university students based on engineering training. Journal of Agricultural University of Hebei (Agriculture and Forestry Education) 6,78-82. 